\title{
IMPROVING ENGLISH SPEAKING BY USING ROLE PLAY TO SEVENTH GRADE OF SMPN 8 CIMAHI IN ACADEMIC YEAR 2016/2017
}

\author{
Andri Abdul Basit ${ }^{1}$ \\ ${ }^{1}$ IKIP SILIWANGI \\ ${ }^{1}$ ilusioner20@gmail.com,
}

\begin{abstract}
This study is conducted in order to develop students' speaking at first grade students of SMPN 8 Cimahi through role play activities. This study is related to the result of a preliminary study showed that the students were still poor in English speaking skill; especially in giving interpersonal response. This study used a Classroom Action Research (CAR) which is conducted to solve the students' problem in English Speaking. The Classroom Action Research (CAR) was done based on Kemmis and McTaggart design. The writer did two cycles in which each cycle consists of planning, acting, observing, and reflecting.The data were gathered through quantitative data. quantitative data were obtained from the students' speaking score of pretest and posttest and questionnaire. The results of this research showed that the use of Role Playing technique was successful to improve the students' speaking. Classroom English helped the students to be more familiar with English, The vocabulary and pronunciation practices and role play performances also helped them to enrich their vocabulary knowledge and build their accuracy. Furthermore, Role Play technique was successful to encourage them to practice speaking. Meanwhile, the use of various media could attract their attention during the class. Based on the quantitative data, the students' mean scores for the speaking skill improved from 8.25 in the pretest to 14.20 in the posttest.
\end{abstract}

Keywords: Speaking, Role Play Technique

\section{INTRODUCTION}

Communication is an essential need for human being. Language as a means of communication has an important role to reveal an intention among people. Since language is important to communicate, it is not enough for students to learn words, phrases, and grammatical features if they want to produce language in their daily communication or to interact with others in English.

\section{Speaking Comprehension}

Many definitions about speaking have been proposed by language theorists. Harmer (2001:269) defines speaking ability as the ability to speak fluently presupposed not only knowledge of language features, but also the ability to process information and language 'on the spot'. It requires the ability to cooperate in the management of speaking turns and nonverbal language. It happens in the real situation and has little time for detailed planning. Therefore, the fluency is required to reach the goal of the conversation.

\section{Teaching for Junior High School}

Brown (2001) states that teaching means showing or helping someone how to do something, giving instruction, guiding in the study of the something, providing with the knowledge, causing to know or to understand. Another challenge of teaching adolescents is their low boredom threshold, which may be a further reason for disruptive behaviour. If the level of the class is too low, they may simply switch off. If it is too high, they may become discouraged and demotivated. 


\begin{tabular}{|c|c|c|c|}
\hline No. & Criteria & $\begin{array}{l}\text { Rating } \\
\text { Scores }\end{array}$ & Description \\
\hline \multirow[t]{5}{*}{1.} & \multirow{5}{*}{ Pronunciation } & 5 & Has few traces of foreign language. \\
\hline & & 4 & $\begin{array}{l}\text { Always intelligible, though one is conscious } \\
\text { of a definite accent }\end{array}$ \\
\hline & & 3 & $\begin{array}{l}\text { Pronunciation problems necessitate } \\
\text { concentrated listening and occasionally lead to } \\
\text { misunderstanding. }\end{array}$ \\
\hline & & 2 & $\begin{array}{l}\text { Very hard to understand because of } \\
\text { pronunciation problems. Must frequently be } \\
\text { asked to repeat. }\end{array}$ \\
\hline & & 1 & $\begin{array}{l}\text { Pronunciation problems so severe as to make } \\
\text { speech virtually unintelligible. }\end{array}$ \\
\hline \multirow[t]{5}{*}{2.} & \multirow[t]{5}{*}{ Grammar } & 5 & $\begin{array}{l}\text { Makes few (if any) noticeable errors of } \\
\text { grammar or word order. }\end{array}$ \\
\hline & & 4 & $\begin{array}{l}\text { Occasionally makes grammatical and or word } \\
\text { order errors which do not, however, obscure } \\
\text { meaning. }\end{array}$ \\
\hline & & 3 & $\begin{array}{l}\text { Make frequent errors of grammar and word } \\
\text { order which occasionally obscure meaning }\end{array}$ \\
\hline & & 2 & $\begin{array}{l}\text { Grammar and word order errors make } \\
\text { comprehension difficult, must often rephrase } \\
\text { sentences }\end{array}$ \\
\hline & & 1 & $\begin{array}{l}\text { Errors in grammar and word order, so severe } \\
\text { as to make speech virtually unintelligible. }\end{array}$ \\
\hline \multirow[t]{5}{*}{3.} & \multirow[t]{5}{*}{ Vocabulary } & 5 & $\begin{array}{l}\text { Use of vocabulary and idioms is virtually that } \\
\text { of a native speaker. }\end{array}$ \\
\hline & & 4 & $\begin{array}{l}\text { Sometimes use inappropriate terms and or } \\
\text { must rephrase ideas because of lexical and } \\
\text { equities. }\end{array}$ \\
\hline & & 3 & $\begin{array}{l}\text { Frequently uses the wrong words; } \\
\text { conversation somewhat limited because of } \\
\text { inadequate vocabulary. }\end{array}$ \\
\hline & & 2 & $\begin{array}{l}\text { Misuse of words and very limited vocabulary } \\
\text { make comprehension quite difficult }\end{array}$ \\
\hline & & 1 & $\begin{array}{l}\text { Vocabulary limitations so extreme as to make } \\
\text { conversation virtually impossible }\end{array}$ \\
\hline \multirow[t]{5}{*}{4.} & \multirow[t]{5}{*}{ Fluency } & 5 & $\begin{array}{l}\text { Speech as fluent and effortless as that of a } \\
\text { native speaker }\end{array}$ \\
\hline & & 4 & $\begin{array}{l}\text { Speed of speech seems to be slightly affected } \\
\text { by language problems }\end{array}$ \\
\hline & & 3 & $\begin{array}{l}\text { Speed and fluency are rather strongly affected } \\
\text { by language problems. }\end{array}$ \\
\hline & & 2 & $\begin{array}{l}\text { Usually hesitant; often forced into silence by } \\
\text { language limitation. }\end{array}$ \\
\hline & & 1 & $\begin{array}{l}\text { Speech is so halting and fragmentary as to } \\
\text { make conversation virtually impossible }\end{array}$ \\
\hline 5. & Comprehension & 5 & $\begin{array}{l}\text { Appears to understand everything without } \\
\text { difficulty. }\end{array}$ \\
\hline
\end{tabular}




\begin{tabular}{|c|c|l|}
\hline 4 & $\begin{array}{l}\text { Understands nearly everything at normal } \\
\text { speed, although occasional repetition may be } \\
\text { necessary. }\end{array}$ \\
\hline 3 & $\begin{array}{l}\text { Understands most of what is said at slower- } \\
\text { than normal speed with repetitions. }\end{array}$ \\
\hline 2 & $\begin{array}{l}\text { Has great difficulty following what is said. } \\
\text { Can comprehend only "social conversation" } \\
\text { spoken slowly and with frequent repetitions. }\end{array}$ \\
\hline 1 & $\begin{array}{l}\text { Cannot be said to understand even simple } \\
\text { conversation. }\end{array}$ \\
\hline
\end{tabular}

\section{Role Playing Technique}

The role playing technique is a method of instruction in which participants act out designated role relevant to real-life situation. The role playing/simulation technique follows from the interactional view. This view "sees language as a vehicle for the realization of interpersonal relations and for the performance of social transactions between individuals. Language teaching content, according to this view, may be specified and organized by patterns of exchange and interaction or may be left unspecified, to be shaped by the inclinations of learners as interactor." According to Ladousse (1987), role play belongs to that category of language learning techniques sometimes referred to as low input-high output. This means that the teacher-centered presentation phase of the lesson is very short and not at all the same as it would be for a controlled practice drill. After a brief introduction, the students plunge into an activity in which accomplishing the task is more important than using the exact word, in which fluency predominates over accuracy. Obviously, the language the students use does not come out of a top hat at the wave of a magic wand, and must have been acquired at an earlier stage.

\section{METHOD}

The type of this research is action research. This action research tries to identify the problem that happened in the teaching and learning class and then decides an action to overcome the problems. In this research, the researcher identified some problems related to the students' speaking skill. Thus, he formulated the actions to solve the problem.

\section{Research Design}

This research is conducted on the basic of classroom action research procedure. Here the writer uses design model of action research by Kemmis and McTaggart design.The main concept of the action research by Kemmis and McTaggartdesignconsists of four components, they are planning, acting, observing, and reflecting. This four phases are considered one cycle. After finishing one cycle, it was continued by the second one.

In improving the students' speaking skill, the researcher decided to conduct action research based on Kurt Lewins in a figure below :

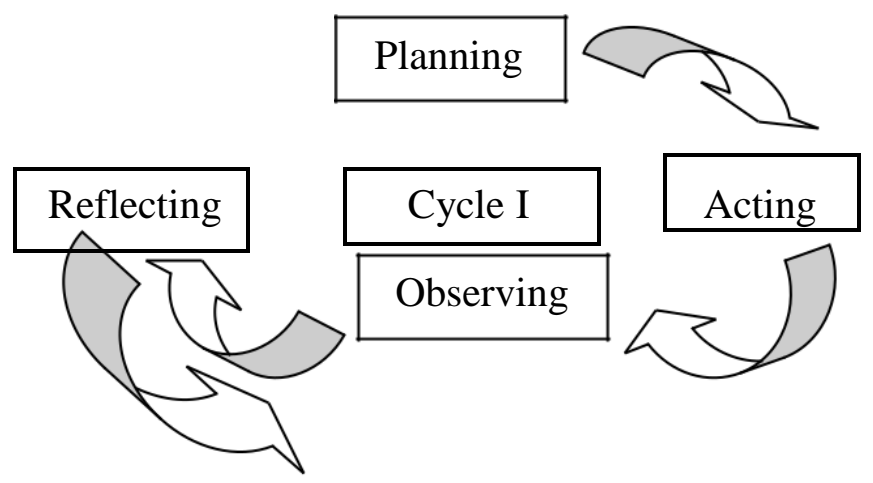




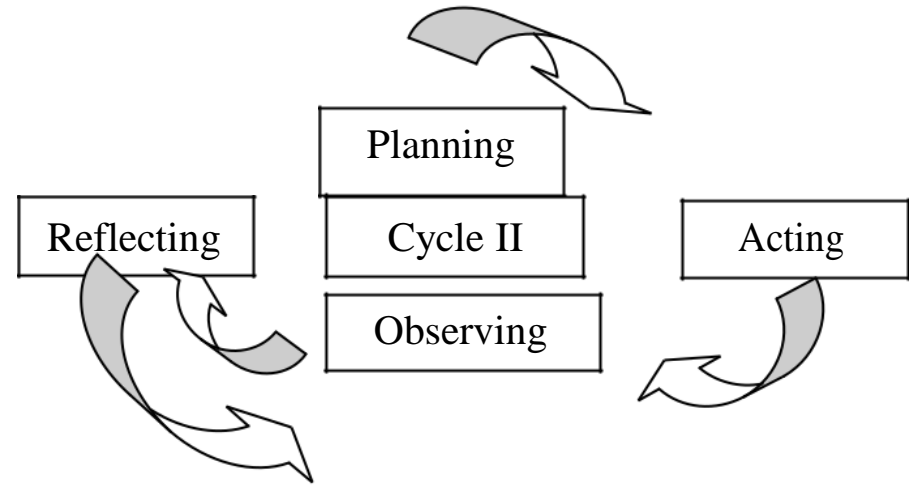

Kemmis and McTaggart design.

\section{Research Subjects}

According to Crowl (1996:15), population are groups consisting of all people to whom a researcher wishes to apply the findings of a study. The Population of the research the students of VII grade of SMPN 8 Cimahi. While, samples are subsets of people used to represent populations (Crowl, 1996:15). The samples of the study are class VIID which consist of 26 students.

\section{Instruments}

In this case, the researcher uses the unstructured observation to get the real condition in teaching learning process. During the observation, the researcher make the observation notes about situation in the class, performance in teaching speaking and students' speaking skills (such as; pronunciation, vocabulary, grammar, and their braveries to speak) and take photograph.

Before implementing the research, the researcher interviewed the teacher about students' difficulties in the speaking skill, students' condition in speaking activity, and the kinds of strategies usually adopted by the teacher in teaching speaking. The researcher also carried the interview after accomplishing the research to know the teacher's response toward the idea of implementing the role play technique in improving students' ability in speaking.

The researcher used the oral test for the students. The test used in this study is the pretest and the post-test. The pre-test was done before implementing role play technique. It was used to measure students' speaking ability at first. Meanwhile, the post-test was implemented after using the role play technique.

The students did the oral test by playing a role. They were asked to choose one of the envelopes of role cards which are provided by the researcher. Then, the students performed their role play. The students needed to do the test in pairs.

\section{Technique of Data Analysis}

The collected data found in this research are analyzed qualitatively and quantitatively. It means that all the data gathered from the observations during learning process, questionnaire, and interview before and after classroom action research are analyzed qualitatively. While the data obtained from tests (pre-test and post-test) are Analyzed descriptive quantitatively (percentage). In completing the numerical data, the writer tries to get the average of students' speaking score within before the the implementation and every cycle in order to know how well the role play technique in the classroom. It is the formula Sudjana (2002:67)

$\mathrm{X}:$ mean

$\mathrm{n}$ : number of students

$\underline{\mathrm{x}}$ : individual score 
Then, the writer tries to get the class percentages which pass the the target score of the minimal mastery level criterion-KriteriaKetuntasan Minimal. It is the formula :

$\mathrm{P}=-\mathrm{X} 100 \%$

$\mathrm{P}:$ the class percentage

$\mathrm{F}$ : total percentage score

$\mathrm{N}$ : number of students

\section{RESULTS AND DISCUSSION}

So based on finding obtained through interview, observation and questionare it can be concluded Using role play in the classroom has many advantages, when the students are participating in role play activities; they are likely to be supportive of their classmates as they understand that putting yourself out there in these types of activities makes you vulnerable. This type of supportive and understanding atmosphere increases empathy among the students. Role play activities give students practice communicating in authentic ways and situations. This will give them more confidence when presented with those scenarios when they are outside of class.

The process students go through when they are doing a role play activity (creating or learning the dialogue, practicing, presenting) will help solidify the new information they are learning. This is in line with the statement put forward by (Celce-Murcia, 1988: 71) Dramatic activities provide "some of the richest and most memorable experiences (students) have in their struggle with the second language". Role play activities can be modified to fit upper and lower level students within the same activity. Lower level students can stick to the previously generated script and upper level students can modify the dialogue or improvise on their own, Students can take on as much or as little spontaneity as they feel comfortable for lower level classes it is proven here in SMPN 8 Cimahi.

The results of the preliminary test and progress test show the improvement in the students' speaking. In quantitative data, before the implementation of the role play in improving students' speaking, the researcher gained the data from the result of preliminary test. In the preliminary test, the mean score of the class before the action was 61.38. Furthermore, the researcher calculated the percentage of students' speaking score in order to know the improvement of the students' who passed the KKM. In the pre-test, it could be seen that the percentage of the students who passed the KKM was about $26.92 \%$. It means there are seven students who passed the KKM (76) and there are nineteen students who get the score below the KKM.

After the researcher calculated the result of the preliminary test, the researcher conducted action research that applied the role play in improving the students' speaking then the researcher identified and calculated the result of progress test 1 . The mean score of students in progress test 1 is 72.92. It means the students' improvement was 11.54 (72.92 $61-38$ ) or $18.80 \%$. Furthermore, the percentage of students who passed the KKM is $53.84 \%$. It showed that there were fourteen students who passed the KKM and there are twelve students who were below the KKM.

Next, after the researcher conducted the cycle 2, the researcher did the Progress test 2 in order to know the improvement of the students speaking in cycle 2 . The mean score of the students in post-test 2 is 76.31, and the improvement of the students' score from progress test 1 to progress test 2 is 3.39 (76.31 - 72.92). Furthermore, it can be seen that the improvement of the students speaking ability from pre-test to post-test is $14.93(76.31-61.38)$ or $24.32 \%$. Then, from the percentage of the students who passed the KKM in progress test 2 is 80.77 , there were 
twenty-one students who passed the KKM and five students were below the KKM, so it has met a criterion success.

\section{CONCLUSION}

Based on the result of data analysis, the writer inferred that teaching English by using role play can improve students' speaking ability. It can be proved through several data such as; preliminary test and progress test. The result of pre-test shows that the students' mean score is only 61.92, and in progress test 1 the students' mean score is 72.92, and in progress test 2 the students' mean score is 76.31, students who passed the KKM, so it was showed the significant improvement in teaching speaking by using role play technique. Moreover by implementing role play in teaching speaking the students have chance to be active and cooperative in speaking activity, role play has various activities that can be effective to teach students in big class, it is supported from the observation and questionnaire data.

\section{REFERENCES}

Arikunto, Suharsismi. Penelitian Tindakan Kelas. Jakarta: Bumi Aksara, 2009. Arini.I.M.(2015) Improving The Student 'Speaking Ability Trought The Use Of Role Playing Technique for Grade VII Student' Of Smpn Banguntapan. A Thesis.Yogyakarta :english language education department faculty of languages and arts state university of yogyakarta. Burns, A. (1999). Collaborative Action Research for English Language Teachers. Cambridge: Cambridge University Press.

Brown, H.D. 2001. Teaching by Principles: An Active Approach to Language Pedagogy. (2nd ed). San Francisco: Addison Wesley Longman, Inc.

Bygate, Martin. 2000. Teaching and Researching Speaking. London: Longman

Harmer, J. 2001.Practice of English Language Teaching. Edinburgh Gate: Longman. Ladousse, Gillian Porter.1987. Resource Books for Teachers: ROLE PLAY. New York. Oxford University Press.

Livingstone, Carol. Role Play in Language Learning. Burnt Mill: Longman Group Limited, 1983.

Nunan, D. (1989). Designing Tasks for the Communicative Classroom. Cambridge: Cambridge University Press.

Nurina. (2011) Improving students' Speaking Ability By Using Role Play (A Classroom Action Research at VII Grade of SMPN 251 Jakarta). A Thesis. Jakarta: English Education Department, Faculty of Tarbiyah and Teachers' Training SyarifHidayatullah State Islamic Unversity.

Richard, Jack C. Developing Classroom Speaking Activities; From Theory to Practice, $<\mathrm{Http}$ ///www.professorjackrichard.com/developing-classoom-speakingactivities.pdf. $>$

Richards, J. C. and Renandya, W. A. (2002). Methodology in Language Teaching; An Anthology of Current Practice. Cambridge: Cambridge University Press.

Richards, J. C. (2006). Communicative Language Teaching Today.Cambrigde: Cambridge University Press.

Ur, Penny. A Course in Language Teaching. Cambridge: Cambridge University Press, 1996.

Wallace, Michael J. Action Research for Language Teachers. Cambridge: Cambridge University Press, 2006. 